\title{
Comparison of Allografts and Prosthetic Valves When Used for Emergency Aortic Valve Replacement for Active Infective Endocarditis
}

\author{
Flavian M. Lupinetti, MD, and John H. Lemmer, Jr., MD
}

Aortic valve replacement (AVR) using allografts is an established method of treating aortic valve disease. It is uncertain, however, whether the increased technical demands of allograft AVR can be justified in emergency operations. This study reports 15 patients treated between 1987 and 1990 for acute bacterial or fungal endocarditis involving the aortic valve. Patients underwent emergency AVR because of severe congestive failure, overwhelming sepsis or cerebral emboli. Eight patients received prosthetic valves (group If 4 mechanical, 4 porcine) and 7 received human allografts (group II: 5 aortic and 2 pulmonary). The groups were comparable in age (group I, 55 years; group II, 51 years), intravenous drug abuse (group I, 1; group II, 3), and previous AVR (group 1, 3; group II, 2). One group I and 4 group II patients had septal abscesses. Additional procedures in group I included mitral valve replacement (2), tricuspid valve replacement (1) and aortic root replacement (1). Additional procedures in group II were mitral valve repair (1), root replacement (1), atrlal septal defect closure (1) and aortocoronary bypass (1). Mean bypass times (group I, 189 minutes; group II, 204 minutes) and cross-clamp times (group i; 108 minutes; group II, 121 minutes) were similar. Operative deaths occurred in 4 of 8 group I and 1 of 7 group II patients. All surviving patients have been successfully followed (group I, 28 months; group II, 18 months). No group I patient has required reoperation. One group II patient required reoperation for recurrent infection affecting the allograft, and another group II patient died 10 months postoperatively from noncardiac causes. All other group II patients are alive and well with

From the Section of Thoracic Surgery, Departments of Surgery, University of Michigan School of Medicine, Ann Arbor, Michigan, and University of Iowa School of Medicine, Iowa City, Iowa. Manuscript received February 19, 1991; revised manuscript received and accepted May 6, 1991.

Address for reprints: Flavian M. Lupinetti, MD, Section of Thoracic Surgery, University of Michigan Hospital, 2120 Taubman Center Box 0344, Ann Arbor, Michigan 48109. functioning allografts. AVR with allografts can be performed safely in this high-risk patient population.

(Am J Cardiol 1991;68:637-641)

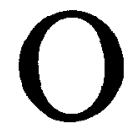
rthotopic aortic valve replacement (AVR) using a human valve allograft was first performed by Ross in $1962 .{ }^{1}$ Lau et $\mathrm{al}^{2}$ and Manhas et $\mathrm{al}^{3}$ extended this operation to the treatment of endocarditis. Since then, several groups have reported their experience with this technique. ${ }^{4-6}$ Allografts may be the preferred substitute for acutely infected aortic valves because of their resistance to infection..$^{7-8}$ Despite the successes of allograft AVR for endocarditis, it is likely that most patients requiring emergency operation in this setting are treated with prosthetic valves. It is possible that some surgeons question the appropriateness of performing a more technically demanding procedure on a critically ill patient. In such a patient, the additional time required for proper insertion of an allograft may be thought to compromise the chances for a successful outcome. To evaluate these questions, we have reviewed our results with emergency AVR for endocarditis.

\section{METHODS}

Patients: The records of patients undergoing AVR for endocarditis between 1987 and 1990 at 1 institution were reviewed. Patients with valvar disease resulting from previous endocarditis that had resolved by the time of operation, patients treated for an extended period with antibiotics to permit AVR under better conditions, and patients with negative blood and valve cultures at operation were excluded from the study. All patients included in this series required emergency operation for 1 or more clinical criteria: intractable congestive failure, overwhelming sepsis, or documented cerebral emboli attributed to valvar vegetations. Records were examined for preoperative information including demographic data, predisposing factors to endocarditis, bacteriologic findings, and cardiac evaluation by echocardiography and cardiac catheterization. Operative 


\begin{tabular}{|c|c|c|c|c|c|c|}
\hline Pt. No. & $\begin{array}{l}\text { Age }(y r) \\
\& \operatorname{Sex}\end{array}$ & $\begin{array}{l}\text { Predisposing } \\
\text { Factors }\end{array}$ & Blood Cultures & $\begin{array}{l}\text { Indications for } \\
\text { Operation }\end{array}$ & $\begin{array}{l}\text { Operative } \\
\text { Findings }\end{array}$ & $\begin{array}{l}\text { Gram Stain } \\
\text { of Valve }\end{array}$ \\
\hline \multicolumn{7}{|c|}{ Group I } \\
\hline 1 & $77 \mathrm{M}$ & Aortic stenosis & S. aureus & Congestive failure & Vegetations & Not performed \\
\hline 2 & $69 \mathrm{~F}$ & Previous AVR & S. aureus & Congestive failure & Abscess & Gram + cocci \\
\hline 3 & $47 \mathrm{M}$ & i.v. drug abuse & Str. sanguis & Sepsis & Vegetations & Gram + cocci \\
\hline 4 & $65 \mathrm{M}$ & Aortic stenosis & Str, bovis & Congestive failure & Vegetations & Not performed \\
\hline 5 & $47 \mathrm{M}$ & 0 & Str. hyacis & Congestive failure & Vegetations & Gram + cocci \\
\hline 6 & $69 \mathrm{~F}$ & Previous AVR & S. aureus & Congestive failure & Vegetations & Not performed \\
\hline 7 & $44 \mathrm{M}$ & Previous AVR & S. aureus & Sepsis & Vegetations & Gram + cocci \\
\hline 8 & $25 \mathrm{~F}$ & i.v. drug abuse & S. aureus & Cerebral embolism & Vegetations & Gram + cocci \\
\hline \multicolumn{7}{|c|}{ Group II } \\
\hline 9 & $50 \mathrm{~F}$ & $\begin{array}{l}\text { Aplastic anemia; } \\
\text { Hickman catheter }\end{array}$ & Str. faecalis & Congestive failure & Abscess & Not performed \\
\hline 10 & $62 \mathrm{M}$ & Previous AVR & C. albicans & Sepsis & Vegetations & Yeast forms \\
\hline 11 & $59 \mathrm{~F}$ & Aortic stenosis & Str. faecalis & Cerebral embolism & Vegetations & Gram + cocci \\
\hline 12 & $62 \mathrm{~F}$ & Atrial septal defect & S. aureus & Cerebral embolism & $\begin{array}{l}\text { Abscess } \\
\quad \text { Atrial septal defect }\end{array}$ & Not performed \\
\hline 13 & $58 \mathrm{~F}$ & i.v. drug abuse & Str. faecalis & Congestive failure & Abscess & Gram + cocci \\
\hline 14 & $24 \mathrm{~F}$ & Previous AVR & S. aureus & Congestive failure & $\begin{array}{l}\text { Abscess } \\
\text { Aorta-RA fistula }\end{array}$ & Gram + cocci \\
\hline 15 & $42 M$ & i.v. drug abuse & S. aureus & Congestive failure & Vegetations & Gram + cocci \\
\hline
\end{tabular}

\begin{tabular}{|c|c|c|c|c|c|c|}
\hline Pt. No. & $\begin{array}{l}\text { Replacement } \\
\text { Valve }\end{array}$ & $\begin{array}{l}\text { Bypass } \\
\text { Duration (min) }\end{array}$ & $\begin{array}{l}\text { Ischemia } \\
\text { Duration (min) }\end{array}$ & Other Procedures & $\begin{array}{l}\text { Operative } \\
\text { Result }\end{array}$ & Long-Term Result \\
\hline \multicolumn{7}{|c|}{ Group I } \\
\hline 1 & Porcine & 137 & 100 & 0 & Died & - \\
\hline 2 & Porcine & 220 & 145 & 0 & Died & - \\
\hline 3 & Porcine & 109 & 60 & 0 & Survived & Alive and well $25 \mathrm{mo}$. po \\
\hline 4 & Mechanical & 116 & 71 & 0 & Survived & Alive and well $26 \mathrm{mo}$. po \\
\hline 5 & Mechanical & 211 & 156 & Mitral valve replacement & Survived & Alive and well $26 \mathrm{mo}$. po \\
\hline 6 & Mechanical & 358 & 93 & Aortic root replacement & Died & - \\
\hline 7 & Mechanical & 227 & 158 & Mitral valve replacement & Survived & Alive and well 34 mo. po \\
\hline 8 & Porcine & 130 & 83 & Tricuspid valve replacement & Died & 一 \\
\hline \multicolumn{7}{|c|}{ Group II } \\
\hline 9 & Allograft PV & 277 & 114 & Mitral valve repair & Survived & Alive and well $21 \mathrm{mo}$. po \\
\hline 10 & Allograft AV & 216 & 135 & 0 & Died & - \\
\hline 11 & Allograft PV & 190 & 137 & Aortocoronary bypass X2 & Survived & Alive and well $8 \mathrm{mo}$. po \\
\hline 12 & Allograft AV & 164 & 120 & Atrial septal defect closure & Survived & Alive and well $13 \mathrm{mo}$. po \\
\hline 13 & Allograft AV & 214 & 125 & 0 & Survived & $\begin{array}{l}\text { Alive; late repeat AVR } \\
24 \text { mo. po }\end{array}$ \\
\hline 14 & Allograft AV & 228 & 127 & Aortic root replacement & Survived & $\begin{array}{l}\text { Died } 10 \text { mo. po of } \\
\text { noncardiac causes }\end{array}$ \\
\hline 15 & Allograft AV & 140 & 87 & 0 & Survived & Alive and well $18 \mathrm{mo}$. po \\
\hline
\end{tabular}

findings, techniques and results were noted. Pathologic and bacteriologic analyses of operative specimens were reviewed.

The choice of valve substitute was made by the surgeon before beginning the operation. The decision to use or not to use an allograft valve was based on the surgeon's experience with and confidence in these materials, and did not reflect any other patient selection factors such as age, cardiac function, hemodynamic instability or associated procedures required. In only 1 case was this decision altered. One patient for whom an allograft was intended had an aortic anulus that exceeded the size of any available allograft. This patient therefore received a porcine valve. For patients in whom an allograft valve was selected, an aortic valve allograft was used when possible. When no aortic allograft was available in the correct size, a pulmonary valve allograft was used instead. Mechanical or bioprosthetic valves were selected in non-allograft recipients based on criteria such as patient age, contraindications to anticoagulation, possible desire for pregnancy, and ability to comply with a medical regimen. Antibiot- 
ic coverage was instituted at diagnosis and continued for 6 weeks postoperatively. Postoperative data were obtained by outpatient follow-up in our clinic, or by phone with the patient and the patient's personal physician. No patient was lost to follow-up.

\section{RESULTS}

Of 15 patients who met the criteria for emergency AVR for endocarditis, 12 underwent operation within 24 hours of diagnosis, all within 48 hours. Eleven patients were taken to the operating room immediately after cardiac catheterization, echocardiography or computerized tomography. Data are summarized in Tables I and II. Eight patients (group I) underwent AVR with a prosthetic valve (4 mechanical, 4 bioprosthetic valves) and 7 patients (group II) underwent AVR with a cryopreserved human aortic valve (5) or pulmonic valve (2).

Group I included 5 men and 3 women and group II included 2 men and 5 women. Groups I and II were similar in mean age (group I, 55 years; group II, 51 years), frequency of intravenous drug abuse (group I, 1 patient; group II, 3 patients), and history of previous AVR with a prosthetic valve (group I, 3 patients; group II, 2 patients). A comparison of patients with native valve endocarditis to those with prosthetic valve endocarditis is listed in Table III. Cardiopulmonary bypass times were significantly longer in patients with prosthetic valve endocarditis, but no other statistically significant differences were found. Additional operative findings were septal abscess in 1 group I and 4 group II patients, mitral valve endocarditis in 1 group $I$ and 1 group II patient, atrial septal defect in 1 group II patient, and aorta-right atrium fistula in 1 group II patient. All patients had positive blood cultures at the time of operation. Cultures of valvar vegetations or blood, or both, in group I patients were positive for Staphylococcus aureus in 5 patients, and for Streptococcus sanguis, Streptococcus bovis, and Streptococcus hyacis in 1 patient each. Cultures in group II patients were positive for Staphylococcus aureus in 3 patients, Streptococcus faecalis in 3, and Candida albicans in 1. All staphylococcal species were sensitive to methicillin.

Additional procedures performed in group I patients included replacement of the mitral valve (2), tricuspid valve (1) and aortic root (1). Additional procedures in group II were mitral valve repair (1), aortic root replacement (1), atrial septal defect closure (1) and coronary artery bypass $\times 2$ (1). Mean duration of cardiopulmonary bypass (group I, 189 minutes); group II, 204 minutes) and aortic cross-clamping (group I, 108 minutes; group II, 121 minutes) were not significantly different.

Perioperative deaths occurred in 4 of 8 group I patients and in 1 of 7 group II patients. Three group II patients with septal abscesses required insertion of per-

\begin{tabular}{|c|c|c|}
\hline & $\begin{array}{l}\text { Native Valve } \\
\text { Infection }\end{array}$ & $\begin{array}{l}\text { Prosthetic Valve } \\
\text { Infection }\end{array}$ \\
\hline Number of patients & 10 & 5 \\
\hline Age (years) & $53 \pm 4$ & $54 \pm 8$ \\
\hline \multicolumn{3}{|l|}{ Indications for operation } \\
\hline Congestive failure & 6 & 3 \\
\hline Sepsis & 1 & 2 \\
\hline Cerebral emboli & 3 & 0 \\
\hline Patients requiring additional procedures & 5 & 3 \\
\hline Cardiopulmonary bypass duration (min) & $169 \pm 17$ & $250 \pm 24^{*}$ \\
\hline Cardiac ischemic duration ( $\mathrm{min}$ ) & $105 \pm 10$ & $132 \pm 10$ \\
\hline \multicolumn{3}{|l|}{ Operative results } \\
\hline Survived & 8 & 2 \\
\hline Died & 2 & 3 \\
\hline \multicolumn{3}{|l|}{ Long-term results } \\
\hline Well without reoperation & 7 & 1 \\
\hline Well after reoperation & 1 & 0 \\
\hline Late death & 0 & 1 \\
\hline
\end{tabular}

manent pacemakers for complete heart block. Two had documented heart block preoperatively. No other significant complications were encountered. All patients with focal neurologic injury attributed to preoperative emboli exhibited improvement after AVR, and no new neurologic problems were encountered.

Mean duration of follow-up has been 28 months in group I and 18 months in group II. One group II patient, who continued to use intravenous drugs, developed recurrent endocarditis 6 months after allograft AVR. This patient was successfully treated medically, and cardiac catheterization demonstrated competence of her allograft valve. She presented to another hospital 18 months after allograft AVR with severe aortic insufficiency. At reoperation, she was found to have a perforation of 1 valve leaflet. Blood and valve cultures at operation were negative. Her allograft was replaced with a porcine valve in accordance with the preference of the surgeon treating her at that time. One group II patient died in a motor vehicle accident 10 months after AVR. All other group I and II patients are alive and well, without evidence of valve dysfunction.

\section{DISCUSSION}

The frequency of endocarditis may be increasing, perhaps due to nosocomial infections resulting from invasive procedures, immunosuppressed states and intravenous drug abuse, among other factors. In addition, a substantial percentage of all endocarditis is encountered among patients with previously inserted prosthetic valves. The bacteriologic characteristics of endocarditis are changing as well. Although the frequency of Streptococcus viridans endocarditis appears to be decreasing, this may actually reflect an increasing frequency of other organisms. ${ }^{9}$ Thus, the need for operative intervention will likely increase as well. Most patients with endocar- 
ditis are best treated nonoperatively unless there is a specific indication for operation. However, endocarditis associated with severe aortic insufficiency and congestive failure is fatal in 40 to $93 \%$ of patients without surgical treatment. ${ }^{9}$ Endocarditis with septic emboli, overwhelming sepsis, intracardiac abscess, conduction disturbance, resistant organisms, suppurative pericarditis or clinical deterioration despite appropriate antibiotics are other indications for AVR.

When operation is indicated for endocarditis, it is preferred that antibiotics be used to control the infection, so that valve replacement may have the highest probability of success. ${ }^{10,11}$ However, inappropriate delay to achieve bacteriologic "cure" may carry excessive risk. $^{12}$ The operative mortality of valve replacement for active endocarditis is 3 to 4 times that for controlled infection. ${ }^{11,13}$ The patients in this series represent the extreme portion of the endocarditis spectrum. All of these patients required emergency operation because of specific clinical findings (hemodynamic collapse, cerebral emboli or septic shock) that were contraindications to even a brief trial of nonoperative therapy. Reports of surgical intervention for active endocarditis often have included patients who underwent operation after lengthy antibiotic therapy ${ }^{14}$ as well as patients with moderate congestive heart failure as an indication for operation. ${ }^{13}$ Nevertheless, reported operative mortality for valve replacement for endocarditis has been as high as $30 \% .11,13-16$

Comparison of published series is made difficult by the wide differences in definitions. "Early" operations for endocarditis have included patients treated for 1 week to 2 months after diagnosis. ${ }^{17-19}$ Most series describing emergency valve replacement for endocarditis report high frequencies of death and early reoperations. ${ }^{13,20,21}$ However, there are reports of patients undergoing emergency valve replacement for endocarditis with survival of $\geq 90 \%$. 22,23

In such an emergency setting, the selection of valve replacement may be influenced by perceived difficulties related to the patient's condition and to technical problems. Considerations of long-term valve function, hemodynamic performance, resistance to reinfection and freedom from anticoagulant therapy may be subordinate to accomplishing an expeditious procedure and improving the patient's chances of operative survival. Although allografts are more resistant to infection, use of allografts requires greater ischemic time and more precise operative technique. As a result, the use of aortic valve allografts for AVR may be questioned.

The results of this series suggest allografts are acceptable replacements even in the most seriously ill patients with endocarditis. Bypass and ischemic times were not significantly greater in allograft recipients. Long-term results of allograft AVR in this setting re- main unknown, although our only patient requiring late reoperation continued to use intravenous drugs after her AVR. The 1 operative death among allograft recipients occurred in a patient with fungal infection of a prosthetic valve, a condition that is fatal in 80 to $90 \%$ of cases. 24,25

AVR for endocarditis was first described in $1965 . .^{26}$ Allograft AVR for endocarditis was first reported in $1970{ }^{3}$ In 1984, Ross's group described aortic root replacement with an allograft for prosthetic valve endocarditis. ${ }^{2}$ Since then, others have established the efficacy of allografts for both freehand AVR and aortic root replacement in endocarditis. ${ }^{4-6}$ The advantages of allografts in patients with endocarditis include resistance to rcinfection, casicr management of root abscesses, and success in severe endocarditis where prosthetic valves have failed. ${ }^{27}$ These advantages are amplified by the excellent performance of allografts with respect to hemodynamics, durability and freedom from thromboembolism. Long-term follow-up after valve replacement for active endocarditis is important. The 5-year survival in these patients is 40 to $79 \%$, with a reoperation rate as high as $13 \% .^{16,19,28}$ Allografts may improve these long-term results. The use of pulmonary valve allografts for AVR has rarely been reported. ${ }^{29}$ Pulmonary allografts require more precise technique because they are less rigid, and their long-term durability is uncertain. However, pulmonary allografts may calcify less than aortic allografts. ${ }^{30}$

In treating endocarditis surgically, the replacement material used is only one factor affecting the results. Prompt intervention, adequate debridement, obliteration of fistulas, resection of mycotic aneurysms, secure suture placement and antibiotic treatment are unquestionably of greater importance. The operative outcome is also heavily dependent on the patient's underlying condition and left ventricular function. We believe the results of this study support the use of allografts for emergency AVR for endocarditis. Further use and more long-term follow-up are needed to fully evaluate the benefits of this approach.

\section{REFERENCES}

1. Ross DN. Homograft replacement of the aortic valve. Lancet 1962;2:487. 2. Lau JKH, Robles A, Cherian A, Ross DN. Surgical treatment of prosthetic endocarditis. Aortic root replacement using a homograft. I Thorac Cardiovasc Surg 1984;87:712-716.

3. Manhas DR, Hessel EA II, Winterscheid LC, Dillard DH, Merendino KA. Open heart surgery in infective endocarditis. Circulation 1970:41:841-848.

4. Kirklin JK, Kirklin JW, Pacifico AD. Aortic valve endocarditis with aortic root abscess cavity: surgical treatment with aortic valve homograft. Ann Thorac Surg 1988;45:674-677.

5. Zwischenberger JB, Shalaby TZ, Conti VR. Viable cryopreserved aortic homograft for aortic valve endocarditis and annular abscesses. Ann Thorac Surg 1989;48:365-370.

6. Tuna IC, Orszulak TA, Schaff HV, Darielson GK. Results of homograft aortic valve replacement for active endocarditis. Ann Thorac Surg 1990;49:619-624.

7. O'Brien MF, Stafford EG, Gardner MAH, Pohlner PG, McGiffin DC. A 
comparison of aortic valve replacement with viable cryopreserved and fresh allograft valves, with a note on chromosomal studies. $J$ Thorac Cardiovasc Surg 1987;94:812-823

8. Matsuki O, Robles A, Gibbs S, Bodnar E, Ross DN. Long-term performance of 555 aortic homografts in the aortic position. Ann Thorac Surg 1988; 46:187-191.

9. Brandenburg RO, Giuliani ER, Wilson WR, Geraci JE. Infective endocarditis - a 25 year overview of diagnosis and therapy. $J$ Am Coll Cardiol 1983:1:280-291.

10. Crosby IK, Carrell R, Reed WA. Operative management of valvular complication of bacterial endocarditis. $J$ Thorac Cardiovasc Surg 1972;64:235-246.

11. Jung JY, Saab SB, Almond CH. The case for early surgical treatment of leftsided primary infective endocarditis. A collective review. $J$ Thorac Cardiovasc Surg 1975;70:509-518.

12. Croft CH, Woodward W, Elliott A, Commerford PJ, Barnard CN, Beck W. Analysis of surgical versus medical therapy in active complicated native valve infective endocarditis. Am J Cardiol 1983:51:1650-1655.

13. Richardson JV, Karp RB, Kirklin JW, Dismukes WE. Treatment of infective endocarditis: a 10-year comparative analysis. Circulation 1978;58:589-597.

14. Young JB, Welton $D E$, Raizner $A E$, Ishimori $T$, Montero $A$, Guinn $G A$, Mattox K, Gentry LO, Alexander JK, Miller RR. Surgery in active infective endocarditis. Circulation 1979;60(suppl I):I-77-I-81.

15. Stinson EB. Surgical treatment of infective endocarditis. Prog Cardiovasc Dis 1979;22:145-168.

16. Stinson EB, Griepp RB, Vosti K, Copeland JG, Shumway NE. Operative treatment of active endocarditis. $J$ Thorac Cardiovasc Surg 1976;71:659-665. 17. Prager RL, Maples MD, Hammon JW Jr, Friesinger GC, Bender HW Jr. Early operative intervention in aortic bacterial endocarditis. Ann Thorac Surg 1981;32:347-350.

18. Suryapranata $H$, Roelandt J, Haalebos $M$, Degener J, Bos E, Hugenholtz PG. Early cardiac valve replacement in infective endocarditis: a 10-year expericncc. Eur Heart $J$ 1987;8:464-470.

19. Cukingnan RA Jr, Carey JS, Wittig JH, Cimochowski GE. Early valve replacement in active infective endocarditis. Results and late survival. $J$ Thorac Cardiovasc Surg 1983;85:163-173.

20. Wilson WR, Danielson GK, Giuliani ER, Washington JA II, Jaumin PM Geraci JE. Valve replacement in patients with active infective endocarditis. Circulation 1978;58:585-588

21. Stultz P, Pfisterer M, Jenzer HR, Hasse J, Gradel E. Emergency valve replacement for active infective endocarditis. $J$ Cardiovasc Surg 1989:30:20-26 22. Sareli P, Klein HO, Schamroth CL, Goldman AP, Antunes MJ, Pocock WA, Barlow JB. Contribution of chocardiography and immediatc surgery to the management of severe aortic regurgitation from active infective endocarditis. $A m$ $J$ Cardiol 1986;57:413-418.

23. Aslamaci S, Dimitri WR, Williams BT. Operative considerations in active native valve infective endocarditis. $J$ Cardiovase Surg 1989;30:328-333.

24. Rubinstein E, Noriega ER, Simberkoff MS, Holzman R, Rahal JJ Jr. Fungal endocarditis. Analysis of 24 cases and review of the literature. Medicine 1975;54:331-344

25. Seelig MS, Speth CP, Kozinn PJ, Toni EF, Taschdjian CL. Candida endocarditis after cardiac surgery. Clues to earlier detection. $J$ Thorac Cardiovasc Surg 1973;65:583-601

26. Wallace AG, Young WG Jr, Osterhout $S$. Treatment of acute bacteria endocarditis by valve excision and replacement. Circulation 1965;31:450-453.

27. Saldanha RF, Raman J, Feneley M, Farnsworth AE. Homograft aortic roo replacement to correct infective endocarditis requiring seven open cardiac procedures. Ann Thorac Surg 1989;47:300-301.

28. David TE, Bos J, Christakis GT, Brofman PR, Wong D, Feindel CM. Heart valve operations in patients with active infective endocarditis. Ann Thorac Surg 1990;49:701-705

29. Lupinetti FM, Lemmer JH Jr, Ferguson DW, Stanford W, Behrendt DM Aortic valve replacement with pulmonary or aortic valve allografts (abstr). Circulation 1990;82(suppl III):III-764.

30. Livi U, Abdulla A-K, Parker R, Olsen EJ, Ross DN. Viability and morphology of aortic and pulmonary homografts. A comparative study. $J$ Thorac Cardiovasc Surg 1987;93:755-760. 